\title{
Types and Causes of Students' Disruptive Behaviors in English Class: A Case Study at Dondaeng Secondary School, Laos
}

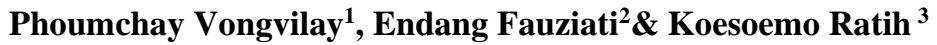 \\ 1,2,3 Universitas Muhammadiyah Surakarta, Indonesia
}

DOI: 10.23917/humaniora.v22i2.13457

Received: January $21^{\text {st }}, 2021$. Revised: March $4^{\text {th }}, 2021$. Accepted: May $24^{\text {th }}, 2021$

Available Online: July $7^{\text {th }}$, 2021. Published Regulary: August, 2021

\begin{tabular}{l}
\hline Keywords \\
\hline classroom management, \\
students' disruptive behaviors, \\
english class
\end{tabular}

Abstract

This study aims to explore the types and causes of students' disruptive behaviors happen in English class. The method of this study was qualitative research. The research type was case study. The data were obtained from observation and interview. The source data were 118 students in level 3. The techniques analyzing data used three steps including data reduction, data

\section{Corresponding Author}

Phoumchay vongvilay

Universitas Muhammadiyah

Surakarta, Indonesia

Email:

s400190006@student.ums.ac.id

Phone: 082135603621 display, and vilification. The results showed that the types of disruptive behaviors happen in the class were class disruption, aggression and goofing off. The causes of students' disruptive behaviors were from the environment around them (friend and social life), bad learning (lazy to study and English is too difficult), and psychology needs (power, freedom, fun). Based on the correlation results, it can be inferred that the types of the disruption that happen in the English class is low behaviors. The environment has more influence for students to make the disruptive behavior in the class. Classroom management is critical in keeping students in a safe and conducive environment for effective learning. Therefore, teachers and principals should add meaning to stimulate and keep going suitable behaviors of students in classroom organizations.

\begin{tabular}{ll}
\hline Kata Kunci & Abstrak \\
\hline Manajemen Kelas, & Tujuan penelitian ini adalah untuk mengetahui jenis dan \\
& penyebab perilaku mengganggu siswa yang terjadi di kelas \\
bahasa Inggris. Metode penelitian ini adalah penelitian & kualitatif. Jenis penelitian adalah studi kasus. Data diperoleh \\
& dari observasi dan wawancara. Sumber data sebanyak 118 \\
& siswa tingkat 3. Teknik analisis data menggunakan tiga tahap \\
yaitu reduksi data, penyajian data, dan vilifikasi. Hasil \\
penelitian menunjukkan bahwa jenis perilaku mengganggu yang \\
terjadi di kelas adalah gangguan kelas, agresi dan goofing off. \\
Penyebab perilaku mengganggu siswa berasal dari lingkungan \\
sekitar (teman dan kehidupan sosial), pembelajaran yang buruk \\
(malas belajar dan bahasa Inggris terlalu sulit), dan kebutuhan \\
psikologi (kekuasaan, kebebasan, kesenangan). Berdasarkan \\
hasil korelasi dapat disimpulkan bahwa jenis gangguan yang \\
terjadi pada kelas bahasa Inggris adalah perilaku rendah. \\
Lingkungan lebih berpengaruh bagi siswauntuk melakukan \\
perrilsh mengganggu di kelas. Manajemen kelas sangat penting \\
dalam menjaga siswa dalam lingkungan yang aman dan \\
kondusif untuk pembelajaran yang efektif. Oleh karena itu, \\
\hline
\end{tabular}




\section{INTRODUCTION}

Classroom management is the process of fostering a learning environment, physical interaction between teachers and students, students and students, parents, and others, encouraging and motivating children to learn, learning, control and governance purposes throughout the school. Its aim is to facilitate and promote cooperation in the organization of teaching and learning activities in the classroom smoothly (Wisetrinthong, Sirisuthi, \& Weangsamoot, 2012).

In the school, disruptive behavior is the action of one or more students threatening to block activities or pull classes into an action program that threatens group safety or violates norms of appropriate classroom behavior of students or school staff (Doyle, 1986). Disruptive behavior is any activity that impedes a student's learning, the learning of other students, and the ability of the teacher. Disruptive behaviors are behaviors that delay normal teaching and learning processes in the classroom (Merrett \& Wheldall, 1986). According to Reed and Kirkpatrick (1998) state the group's talkative behavior is causing chaos, avoiding funny work, interfering with teaching activities. According to Myers (2004), students can act disruptive behaviors because they feel bad, they are tired or sick, they are doing too challenging, and they are nervous, anxious or disappointed or have serious problems.

One of the problems in schools that arise in the classroom regarding the instructional process is that students engage in harassing behaviors that students perform in class which can disturb teachers and other students in the class. Therefore, the teaching and learning process is inefficient. There are some types of student disruptive behaviors, such as back row diversion: students who tend to sit in the back and distract others. Non-attendance: Some students who have not been participated in the assigned class activities. Excessive productive students: the wise students, but it stands out and monopolizes all activities in the classroom. (Richards \& Renandya, 2002). According to Madison (2011) explains disruptive behaviors can adversely affect the classroom environment, including the educational experience for students enrolled. Disruptive behaviors refer to any behaviors that hinders the ability of an instructor or student to learn (Setyadi et al, 2020). Here are some of the more common types of harassing behavior, including but not limited to: eating in class, taking another child to class, monopoly, class discussion, and disrespect for the right of other students to express their opinions. Chatting when the teacher or other person continues to discuss questions or interruptions that interfere with the instructor's presentation (e.g. sleeping or reading paper in class) making too loud noises, going late in class or leaving early, use a pager or mobile phone in the classroom, improper or 
improper need for poor time or attention to personal hygiene (such as an obviously disgusting body odor) and refused to follow the advice of the faculty direction.

Students who exhibit this type of behavior are expecting a warning from their instructor or expelled from an upcoming lesson. Failure to adjust this behavior may result in dismissal from the course. More types of students' disruptive behaviors include, but are not limited to: using of offensive or offensive language, excitement, verbal harassment against a teacher or other student (such as taunts, intimidation, intimidation), intimidation, intimidation, or intimidation, treating to harm oneself or other students and making physical disruptive (Madison, 2011). Moreover, Charles (1999) clarifies five types of student behaviors namely: 1) aggression: using some physical and verbal attacks against teachers or other students; 2) immorality: student acting such as cheating, lies and theft; 3) authority defiance: denying what the teacher requested; 4) classroom disruptions: students talked loudly, called out, walked around the room, the clown threw an object; 5) goofing off: tricked into sitting, not working as assigned.

It cannot be denied that the different nature of students they bring into the classroom can lead to problems. Common problems teachers often find are related to disruptive behavior. It is a behavior that changes the classroom positively too negatively or disrupts normal classroom climate (Davis, 2007). This behavior is one of the causes of teacher stress and becomes a causes that can reduce the effectiveness in teaching and learning process. Teachers typically report that the teaching and learning process cannot be carried out successfully because students find that students indirectly show ignorance of the lesson or classroom activity, interfering with activities such as ignoring the lesson being explained. Teachers talking on the phone, texting, sleeping with friends, leaving class repeatedly without the teacher's permission, and much more. It is believed that when students do this behavior, they have both psychological and physical effects on other students, including teachers.

Homans (1962) states reaction is the activity of students and other students that motivate this action. Glasser (1998) describes Disruptive behaviors are greatly increased in both the school environment and the family environment. Individuals have a responsibility to choose thoughts and behaviors that influence their feelings and psychology. Alternative theories assume that behavior appears within or without psychology. Psychological issues can cause an unhappy relationship with God (Nasucha et al, 2019). Humans arise from five encoded genetic needs: survival, love and ownership, power, freedom, and fun. Choice theory also assumes that each of us owns what is known as our world. The qualities we value for everything or everyone we meet in life that make us feel good or that are imagined will make us feel good. 
Charles (2008) indicates teachers had power that comes from knowing students' abilities, knowing why students set boundaries, and knowing what aspects students have learned. Usually the teacher have been conveyed the intonation, word selection, and presentation method. Teachers also needed to show approval and appreciation when students comply with rules cooperatively, along with what teachers have been done when students engaged in disruptive behavior in class

The study was conducted by Nuray GÜLEÇ (2014) found that using mobile phones during lessons, arguing or disagreeing with other teachers or students, vulgar or rude words, or teacher responses, cheating, and not studying regular. In addition to that, a study by Sun \& Shek (2012) found talking out of turn, following by non-attentiveness, daydreaming, and idleness were the most common and disruptive problem behaviors. Disrespecting teachers in terms of disobedience and rudeness, followed by talking out of turn and verbal aggression were the most unacceptable problem behaviors. In addition to that, a study by Sri Sufahmiat, (2015) indicated that there are behaviors that cause complications such as sleeping in class, talking out answers without raising their hands, cheating, leaving the classroom unhappy, and stupid comments to get attention. Moreover, the study was conducted by Sella, (2015) demonstrated that two types of inappropriate behaviors occurred in English language classes. The verbal abusive behavior that consists of talking, shouting, laughing, singing a song, asking repeat again, returning to talking to the teacher, and crying were the first category. The second type is disruptive behaviors, which consists of walking around the class, teasing classmates, running in class, destroying something, changing seats, dancing, drinking, sleeping, clipping and rolling. Furthermore, the study was conducted by Rehman Ghazi, Shahzada, Tariq, \& Qayum Khan (2013) showed that the harassing behavior of high school students in Pakistan requires widespread attention from educators, policymakers and the government has been managed this area for quality education in the country. For this purpose, appropriate training may be provided for administrators and teachers to engage them in disruptive behaviors and classroom management.

This study was a first study in Dondaeng Secondary School to conduct the types and causes of students' disruptive behaviors. The researcher conducted in level 3 because the students were all teenagers. They did not some adaptation with their classmates and the atmosphere in the class. So, they behaved as not students during teaching learning process. Students often think that English is not important because it is not the dominant language in high school. Most students don't like English because they feel learning English is not easy. They did anything with friends during teacher explained the lesson and it disturbed other students in the class and made the teaching learning process ineffectively.

Disruptive behavior is a complex problem to solve. Researchers are interested in studying the various types and causes of disruptive behavior among 
students in schools. Feeling the need to focus on students' disruptive behavior in research to address some of the major problems associated with their impact on classroom management. Therefore, for this reason, this research aims to explore the types and causes of the students' disruptive behaviors happen in English class.

\section{METHOD}

This was case study; an in-depth analysis of events, groups, societies, communities, or systems that are bound in their natural contexts (McMillan, 2008). The researcher used qualitative data analysis. The setting of this research was conducted at Donedaeng Secondary School, Pathoumphone District, Champasak Province, Laos. The subject of this research were 118 students in level 3 (grade 5, 6, and 7). The techniques collecting data, the researcher used observation and interview. Focusing of observation was the students' disruptive behaviors types; focusing of the interview was students' disruptive behaviors causes. The researcher observed students' behaviors during English teaching learning process to explore the types of the students' disruptive behaviors. The researcher interviewed the students who have disruptive behaviors in the class to unearth the cause of the students' disruptive behaviors. In analyzing data collection, researchers used three steps including data reduction, data display, and vilification (Miles \& Huberman, 1984). In data reduction, researcher reduced from the result of observation, and remove unnecessary information. For data display, the researcher organized the information in the form of narrative for answering the research problems. In the vilification, the researcher summarized the data in the form of dense sentences statement.

\section{RESULT}

This part describes the results of the finding. The types and causes of students' disruptive behaviors happen during the English class were presented below.

\section{Types of Students' Disruptive Behaviors}

Based on the observation, the researcher found that there were three types of students' disruptive behaviors according to Charles (1999).

\section{a. Class Disruption}

Class disruption is behavior that violently or repeatedly interferes with classroom learning. Some types of disruptive behaviors include bullying teachers or others with physical violence, confused or erratic behavior, problems in sleeping or talking late in class, shouting at classmates, reading newspapers or other content, using cell phones, and other distracting actions (Charles, 1999). Based on the result of observation, the types of disruptive behaviors happen in the class that was classified to class disruptions were using a mobile telephone 
during the lesson (e.g. sending messages and playing games), joking during the lesson (e.g. making a loud noise and ignoring the teacher's explanation, sitting in a group laugh together), talking out of turn (e.g. coming to the other student's seat, always asking permission to go to the toilet), and calling names of other students(e.g. calling other students names when the teacher explains the lesson, provoking the back of student sitting in front of him), and whistling(e.g. whistling to greet the girl, and laughing with friends).

\section{b. Aggression}

The aggression results come from students' lack of awareness, sensitivity to the needs of others. Additionally, slightly physically aggressive behavior is sometimes a sign of boredom, a need for attention, and a way of gaining social status. Based on the result of the observation, the types of disruptive behaviors happen in the class that was classified to aggression that happen in the class were arguing or disagreeing in the classroom (e.g. student is so poor in writing by hand that it makes other students look down on it, moving to a friend's seat to ask about writing), and making verbal abuse towards other students (talking dirty with a strong voice to the friend).

\section{c. Goofing Off}

Goofing off is any behavior that is considered a routine behavior that includes being tricked into sitting, not doing the work assigned (Charles, 1999). Based on the result of the observation, the types of disruptive behaviors happen in the class that was classified to goofing off were being late for school or lesson(e.g. student was late for class, other students ignore the teacher's explanation), getting out of seat (or workplace) without permission (e.g. changing his/her seat to other places, sitting in a group of three or even four), not studying regularly(e.g. Drawing a picture or doing something during the learning process), calculating work avoidance (e.g. not writing the answer into the text book), and walking around during the lesson(e.g. not sitting on their seat, walking to other students' seat to make the conversation).

\section{Causes of Students' Disruptive Behaviors}

Based on the interviewed, it can be unearthed that their causes that influence students to behave disruptive were the environment around them, bad learning, and psychological needs.

\section{a. The Environment}

The environment can not only have a positive influence, but it can also be a negative point of view. The environment varies with the behavior and background of different people. Based on the result of interview, the plurality of the students felt that their behavior was influenced by their environments. As the 
following excerpt, students given a reward in the form of additional value and recognition.

If we had friend who stubborn, we would be stubborn students, but if we had good friends and liked studying, we would be good students and liked studying too. Making disruptive behaviors I felt that it was not difficult because my friend has influenced me to make some troubles in the class. So I tried to make new friends when I studied at school.

The excerpt above showed that the cause of students' disruptive behaviors was classified to the environment was affected from their friends and social life. This means that their friends are important people in raising other that may contribute to a student's negative or positive behavior. In addition, social life is a part of time when one person spends fun things with others in the surrounding area or in public.

\section{b. Bad Learning}

Bad learning means as being unable to read and understand simple passages or lessons. Most students find it difficult to learn English. Students feel that they cannot understand English better. In this case, the result of not being motivated to learn English is a lack of willingness to study. As the following excerpts data, a statement was given by the students in the form of additional value and praise.

I am lazy to study English, but I cannot absent the class because my teacher drops my score. I like doing anything apart from the lesson, and talk with friends in the class. I think my voice not disturb the other students. But, they even never complained me. I felt that English is difficult to learn and usually hard to understand. I felt bored because I do not understand at all and even though, I do not understand how to spell the words in English. English made me to fell lazy to study in the class.

In the statement case above showed that the cause of students' disruptive behaviors was classified to the bad learning were lazy to study English, and English is difficult to study. This means one of the things students experience is a struggle to overcome academic laziness. It is the time when students have school work to do, but they still don't feel like doing. Laziness prevents students from having to do important work and can hinder their studies. In addition, English is a second language to study in the school. Therefore, there are many causes that make English difficult and confusing in learning, such as grammar structure, words spelling, words meaning, pronunciation.

\section{c. Psychological Needs}

In accordance with psychological needs contribute the students' disruptive behavior in learning English. All behaviors are uncompromising. This was our best effort at that time, providing up-to-date knowledge and skills to meet at least one of the basic human needs, evolving over time and becoming part of the 
structure. This need is a general stimulus for everything we do. As the following excerpt was given by student in the form of additional value and praise.

If I had power, I would be survival in this world and had the freedom to do a lot of things to get more fun with my friends and other one in the class. The freedom had more influence to make disruptive behaviors in the class. Freedom was important because it allow me to be myself". The fun was as the important thing in my life. If I were fun, I could do everything easily and happily in my studying and in my life.

Based on the excerpt above, the cause of students' disruptive behaviors was classified to the psychological needs were freedom, power, and fun. This means the students need were often viewed negatively. These needs take additional positive indicators of fundamental human needs such as success, internal control, or success. Struggling for too much need or experiencing themself without power, freedom and fun can result in unhappiness and the need for counseling.

\section{DISCUSSION}

\section{Types of Students' Disruptive Behaviors}

The big problems in school happening on teaching - learning process is presence of students' disruptive behaviors that many teachers would like to manage with them. This research explores 3 types of students' disruptive behaviors; they were class disruption, aggression and goofing off. The types of defiance of authority and immortality were never happens in the class. The types of class disruption are using a mobile telephone during the lesson, joking during the lesson, talking out of turn, calling names of other pupils, and calling names of other pupils. The types of aggression are arguing or disagreeing in the classroom, and making verbal abuse towards other pupils, and the types of goofing off are being late for school or lesson, getting out of seat (or workplace) without permission, not studying regularly, calculating work avoidance and walking around during the lesson. It is in line with Charles (1999) describes misbehavior as behavior that is "unsuitable for the setting and situation in which it occurs" (p.2). He emphasizes that student misbehavior occurs intentionally, not inadvertently, that is students purposely do something they know they should not do.

This is in line with Nuray GÜLEÇ (2014) work, which indicated that using mobile phones during lessons, arguing or disagreeing with other teachers or students. As stated by Meyers (2003), disruptive behavior of students when exposed (open and observable behavior such as talking during class, using mobile phones, eating, and drinking) or secretive (passive behavior such as sleeping in the class, getting late from class early, showing boredom and easing; and the most common and disruptive behaviors are chatter followed by inattention, daydreaming, and lethargy. As state by Sun \& Shek (2012), who found that Disrespecting teachers in terms of disobedience and rudeness, 
followed by talking out of turn and verbal aggression were the most unacceptable problem behaviors? This research is in line with Charles (1999), the classroom disruptions are any behaviors that greatly or repeatedly interferes with classroom behavior, such as intimidating the teacher or others with physical violence, confusing behavior, sleeping, talking late, shouting at classmates, reading newspapers or other media, use of cell phones, and other acts that may annoy others.

This study can be expressed that the attitudes, though, family and backgrounds of the students were different. These mean that they has their own self' behaviors and has different thought. The environment around him / her can affect their behavior and it can be positive or negative. In classmate, they have friends that can affect their behaviors, and the teachers also can adjust their negative behaviors to be a good one. Behavior is a learning process from activities that students repeat often and can be automated without thinking. Students will continue to do their behavior in their classroom activities, as a result, they will create negative classroom actions on other students... As stated by Corrie (2001) identifies disruptive classroom behavior due to the need for continuous supervision, refusing to listen the advice, often sought attention and preventing others from learning by chatting, touching, or disrupting their books, materials, and equipment, often playing pencils and other objects, starting to work slowly, speaking out, not motivated, easily distracted by work.

This is not consistent with theory of Robertson et al. (2003) who indicated that malicious teasing is a common misbehavior in classes and it includes cheeky or rude remarks or replies to the teacher. Students encouraged confrontation with teachers or by making them ridicule in subtle ways; they can be excited in the eyes of their peers. In addition, this is not also consistent with the study by Nuray GÜLEÇ (2014) work, her research indicated that types of students' disruptive were vulgar the rude words, or teacher response, and cheating. Moreover, it is not consistent with the theory of Burden (1999) that he focused disruptive student behaviors range from mildly to severely disruptive. Violence, vandalism, coercion, robbery, burglary and drug use are extremely disruptive behaviors. These behaviors often appeared outside of the classroom, in the lunchroom, corridors, or outdoors. In addition, this finding is not consistent with the study of Sri Sufahmiat, (2015) indicated that there were behaviors that cause complications such as sleeping in class, leaving the classroom unhappy, cheating, calling out answers without raising your hands, and stupid comments to get attention.

It can be expressed that the use disrespectful language toward the teacher and insulted the teacher were not encountered behavior in the classroom. By the reason, because of this school was located in rural area. The students had good attitude to teachers. So, this result means that the pluralities of the students in the participants' classrooms were respectful to their teachers, and they have a good 
relationship with teachers. The researcher assumed that the students do not make these behaviors because they get good instruction from their teachers, parents or family. They did not have natural or positive aggressive behaviors, mainly aimed at defending themselves or fighting prejudice or social injustice. Pathological or hostile aggression for the sole purpose of hurting others, and is often the result of their inner nature, corrupt or irritable. Most students wouldn't like to be angry and aggression. They would rather be treated like adults and met their needs.

This finding is affirmed by Sella, (2015) found there are two types of inappropriate behaviors that occur in English language classes. The first category is verbal abusive behavior such as talking, shouting, laughing, singing, asking again, returning the teacher and crying. The second type is misbehavior, which consists of walking around, teasing classmates, running away, destroying toys, changing seats, dancing, drinking, sleeping, clipping and rolling. In addition to that, it is in line with Istianatul, (2019) found that students of all kinds of disruptive behaviors were dealing with personal belongings, using electronic devices, drawing pictures, calling friends, having disruptive or freaking conversations, pricking their classmates, daydreaming, changing seats, joking, playing, and act indifferent.

The research can be seen that they are all teenagers which they might do anything that make them to have fun and freedom with their friends. In addition, many students valued their personal relationships here and now than their education or the future. Some students preferred to focus on the coolness of not participating in any activities or discussions than engaging in their studies. Some students retained the natural curiosity of science with appropriate teaching strategies and motivation. Many students still thought science is interesting, especially if it can be made relevant to their lives.

\section{Causes of Students' Disruptive Behavior}

The study found that the results of the causes of students' disruptive showed that there were 3 causes that making students to behave disruptive; they are environment around them (friends and social life), bad learning (lazy to study and English is too difficult), and psychological needs (power, freedom and fun).

The current study, it can be expressed that most students do some reactions with the other students during teaching and learning process. The spontaneous reaction leads to different behaviors. Students engage these interactions with other students as part of activities during classroom activity. Their behavior in the classroom can be affected by peers or teachers, but they have a life outside of school. There are different types of themselves actions and their habits are dictated by the habits of the other around them. It is in line with Rehman Ghazi, Shahzada, Tariq \& Qayum Khan (2013) work; their finding found that the causes of students' disruptive behaviors informed by teachers were almost identical to 
those seen from different social backgrounds. As stated by Homans (1962), the reaction is the activity of students and other students to encourage action.

This finding found that the cause of students' disruptive behaviors is not consistent with the study by Sri Sufahmiat, (2015) works; his results showed that there are 4 factors that cause students to behave inappropriately; they are poor teaching, poor parenting, the environment and psychological factors. It can be expressed that students have a good relationship with their parents or family. They agree with techniques of the teachers teach English in the class. They are bad in learning because of their abilities in learning English. They felt that friends and environment around them were the causes to engage them to make disruptive. They seem that social life can make studying easier. They do not enjoy studying alone, and it is easier to study if someone helps them. In addition, students feel lazy to take part in the lessons. They do not invest in academic goals, lessons are beyond academic ability, or lesson timing is too slow. When students are lazy, sometimes they find happiness from making their teachers angry or doing something bad. Moreover, they felt hard to study and don't understand the lesson because they had problems with their learning English. Some English words, they could read but it was incorrect accent. They chose to do another noisy thing with their classmates.

It is in line with the theory of Myers (2004) says that students can exhibit disruptive behavior because they feel bad, they are tired or sick, they are doing something too challenging, they are worried, upset, disappointed, or have serious problems. Based on the finding result, the researcher concurred on the theory of choice that assumes that each of us has a so-called world of qualities that holds everything or everyone we meet in life that makes us feel good, or imagine it would make us feel good. It can be assumed that these can provide individual student behavioral actions and different behaviors and life backgrounds. Choice theories also assumed that behavior comes from internal or internal psychology.

\section{CONCLUSION}

In this study, the researcher can be concluded that the students' disruptive behaviors happen in the English class consist of 3 types; they were class disruption, aggression and goofing off. The causes that influence the students to make disruptive behaviors were the environment around them, bad learning, and psychological needs. The researcher can be concluded that the types of the disruption that happen in the English class at Dondaeng Secondary School is low behaviors. The pluralities of the students at this school are good attitude and behaviors to their teachers. They are respectful to the teachers and have awesome relationship with their teachers. In addition, the environment affects students to make disruptive behaviors in the class.

\section{REFERENCES}


Charles, C. M. (1999). Building classroom discipline. (6th Ed.). New York: Longman.

Glasser, W. (1998). Choice theory: A new psychology of personal freedom. New York: Harper Collins.

Istianatul. (2019). Teacher's Strategies in Handling Students' Misbehavior in English Class of Junior High School 22 Surabaya. A Thesis. English Teacher Education Department, Faculty of Education and Teacher Training, Sunan Ampel State Islamic University Surabaya.

Madison, J. (2011). Disruptive classroom behavior. The university of Delaware and Virginia Teach

McMillan, J. (2008). Educational Research. Fundamentals of the Consumer (5th Ed.). Virginia Commonwealth University. NY: Pearson Education Inc.

Merrett, F., \& Wheldall, K. (1986). Observing Pupils and Teacher in Classroom (OPTIC): A behavioral observation, schedule for use in school. Education Psychology, 6(1), 57-70. https://doi.org/10.1080/0144341860060107

Miles, M. B. \& Huberman, A. M. (1984). Qualitative data analysis. London: Sage.

Nasucha, Y., Sabardila, A., \& Pratiwi, D. R. (2019). Identifikasi Bentuk Pembinaan Sekolah Terhadap Siswa dengan Perilaku Juvenile Delinquensi. Jurnal Penelitian Humaniora, 20(2), 98-104.

Nuray GÜLEÇ. (2014). Disruptive Student Behaviors in University Preparatory Classes Observed by Teachers of English .International Journal of Language and Literature, 3(2), 56.https://doi.org/10.23887/ijll.v3i2.20838.

Reed, D. F., \& Kirkrpatrick, C. (1998). Disruptive students in the classroom: A review of the literature. Metropolitan Educational Research Consortium, Richmond, VA, USA

Rehman Ghazi, S., Shahzada, G., Tariq, M., \& Qayum Khan, A. (2013). Types and Causes of Students' Disruptive Behavior in Classroom at Secondary Level in Khyber Pakhtunkhwa, Pakistan. American Journal of Educational Research, 1(9), 350-354. https://doi.org/10.12691/education-1-9-1.

Richard, J. C. \& Renandya, W. R. (2002). Methodology in language teaching: An anthology of current practice. Cambridge University.

Setyadi, Y. B., Anggrahini, T. O., Wardani, N. P. K., Yunanto, W. N., Setiawati, O. T., Hidayati, G. N., ... \& Nugroho, I. (2020). Penerapan Budaya 5S sebagai Penguatan Pendidikan Karakter Siswa di MTs Muhammadiyah 9 Mondokan, Sragen. Buletin KKN Pendidikan, 1(2), 70-76.

Sufahmiat, S. (2015). Students' Disruptive Behavior in Learning English. Jurnal Studi Guru Dan Pembelajaran, 2(3), 241-245. https://doi.org/10.30605/jsgp.2.3.2019.47

Sun, R. C. F., \& Shek, D. T. L. (2012). Student classroom misbehavior: An exploratory study based on teachers' perceptions. The Scientific World Journal, 2012. https://doi.org/10.1100/2012/208907

Suprehatiningsih, C. S. (2015). Classroom Management in English Class of Pangudi Luhur Elementary School Yogyakarta. Yogyakarta: Sanata Dharma University

Wisethrinthong K., Sirisuthi C., \& Weangsamoot V. (2012). The development of classroom management system for the educational extension schools. European Journal of Social Sciences, 30(2), 313-320. 